\title{
Financial Accountability Framework for Local Municipalities in the North West Province
}

\author{
A. J. Mothupi ${ }^{1}$, W. Musvoto ${ }^{1} \&$ J. N. Lekunze ${ }^{1}$ \\ ${ }^{1}$ Faculty of Economics and Management Sciences, North-West University, South Africa \\ Correspondence: A. J. Mothupi, Faculty of Economics and Management Sciences, North-West University, South \\ Africa. \\ Received: October 19, 2021 \\ Accepted: January 11, $2022 \quad$ Online Published: February 17, 2022 \\ doi:10.5430/ijfr.v13n1p74 \\ URL: https://doi.org/10.5430/ijfr.v13n1p74
}

\begin{abstract}
Achieving a clean audit report has been almost impossible for the local municipalities of the North West province due to mismanagement of financial resources by the municipal role-players. In this regard, this study was aimed at exploring the key enablers to achieve financial accountability as well as propose a framework for financial accountability. The Stewardship Theory underpinned this study which emphasises the need for public servants to serve their employers with utmost truthfulness. The social constructivist research paradigm and a qualitative research approach was adopted. An exploratory research design was applied and a semi-structured interviews was used as a data collection method. A total of thirty six participants participated in the study. At the end of data collection, Atlas-ti software (version 8.2) was used to analyse data. Themes and categories were presented using Atlas-ti network diagram and these were well interpreted and discussed. Findings obtained from the study indicated that the key enablers of municipal financial accountability include the facilitation of policies and legislation, the facilitation oversight functions of the Municipal Public Accounts Committee, risk management, benchmarking, internal control, and financial management. These factors were investigated in the empirical study and it was discovered that all are key enablers towards achieving financial accountability except benchmarking which was regarded as a growth tool. Added to these factors are the contributions to the body of knowledge which include training of financial employees and the implementation of consequence management against role-players who do not abide with the financial policies and legislation of the municipalities. The study recommends above all, that the municipality role-players (financial employees) should be adequately trained to ensure competency, MPAC should effectively conduct their oversight duties and recommendations, also legal actions should be adequately taken on all culprits without fear or favour. This is in an endeavour to enhance financial accountability of local municipalities in the North West province.
\end{abstract}

Keywords: financial accountability, key municipal accountability enablers, clean audit report, equitable service delivery, local municipalities, South Africa

\section{Introduction}

Local municipalities in South Africa can improve their proposition for effective service delivery, good maintenance culture, and economic development if they entrenched effective financial management practices. Although there exists legislative precedents guiding financial practices in the local municipalities of South Africa (Public Financial Management Act (1 of 1999), Municipal Financial Management Act (56 of 2003), Municipal Systems Act (32 of 2000), Municipal Structures Act (117 of 1998), reports from the National treasury on South African local municipalities reveals high levels of municipal financial misappropriation. The misappropriation have resulted to the persistence of irregular, unauthorised and wasteful expenditures. Furthermore, the inability of the local municipalities in South Africa to promote accountability and transparency of public funds is concerning and raises questions around the management of these local municipalities.

Although management is viewed as the realisation of organisational objectives through proper leading, planning, coordinating, directing and organising, Pauw et al. (2013) opined that, effective financial management practices that goes beyond leading, planning, coordinating, directing and organising should be adopted by local municipalities across South Africa to realise their objectives. The actualisation of municipal financial goals requires assessing financial prospects, formulating appropriate financial strategies and implementing financial strategies that suit the obligations of the organisations. Local municipal accountability on the other hand refers to the process of being answerable for the 
decisions that have been made, or actions that have been taken by municipal role-players. Lack of accountability in the local municipalities is viewed as a fundamental for governance failures in South African local municipalities.

South Africa enacted the Municipal Financial Management Act (56 of 2003) to promote equitable financial practice by all municipalities, cooperative and consultative governance as well as justifiable governance. This act focus too much on equitable financial practice by all municipalities, cooperative and consultative governance with limited emphasis on financial accountability framework. The weakness of the Municipal Financial Management Act (56 of 2003) to adequately address financial accountability gaps have led to persistent unclean audits by local municipalities across South Africa. The current study is aimed at the development of an accountability framework to enhance the management of local municipal finance through effective financial management practices. The study focussed on the North West province of South Africa of which almost all the local municipalities have been receiving unclean audit from the Auditor's General since 2003.

\section{Stewardship Theory}

Stewardship theory considers the relationship between principals and agents based on the premise on behaviour that is different from Agency Theory. Managers' acts and tasks are guided by the need for self-realization through successful execution of their duties to attract recognition from directors (Caers et al., 2006). Managers have reasons which are compatible with organisations' main goals and there is no financial motive behind managers' behaviour (Stanleigh, 2016). Managers act in accordance with the organization's interests and consider themselves as committed citizens and act responsibly in resource management (Banerjee, 2015; Pauw et al., 2013). They choose to exercise their authority for long-term corporate goals to which they are accountable and also put the entity's interests above their self-interest.

Stewardship theory suggests that managers are answerable to resource owners, ensuring effectiveness, profiting resource utilization, and securing success and sustainability. Cossin, Ong and Coughlan (2015) sustain that stewardship means a long-term desire to work towards the sustainability of an organisation's success. To guarantee sustainability in the local municipal context, municipal financial report must be handled properly, as it acts as a good means of measuring management stewardship by the owners (Hannafey \& Vitulano, 2013). Lopes (2012) upholds that it involves analyzing past financial information to know managers ' current performance and to forecast their future performance. To boost organisation's sustainability, this knowledge assists in determining management capability, trustworthiness and the likelihood of a constructive dialog between management and owners (Lopes, 2012). The management accounts and reports to the owners on how the financial resources entrusted to his responsibility has been utilized (Segal \& Lehrer, 2012). The management may be asked to explain on some vital issues or decisions in the account information. In effect, they must communicate why they did a specific act and just what they did. The provision of credible financial reports by the management improves integrity and enhances administrative transparency.

Unlike the Agency Theory where agents act unscrupulously and driven by economic issues, Stewardship Theories are based on higher-level needs basing on satisfying personal values and ambitions (Segal \& Lehrer, 2012). Servants in an organization act responsibly to the consequences of organizational behavior. The problem of equilibrium is the answer to personal responsibility for community wellbeing. Servants must aim to balance the responsibility of external and corporate stakeholders, as well as adhere to the social environment and social norms. The steward theory as presented in Figure 1 depicts that the principals hire and delegates the agents while having their self-interest. Also, the agents performs and reports to the principal and do have their own self-interest (Segal \& Lehrer, 2012). The agents safeguards and exploits shareholders wealth through selfless performance and are fulfilled and driven when success is accomplished in the organisation. The stewardship theory stresses that both the principals and the agents should act autonomously to attain success. This implies that the agents should by transparent, dedicated, accountable and diligent while the principal should always corporate and collaborate with the agents to achieve desired goals. 


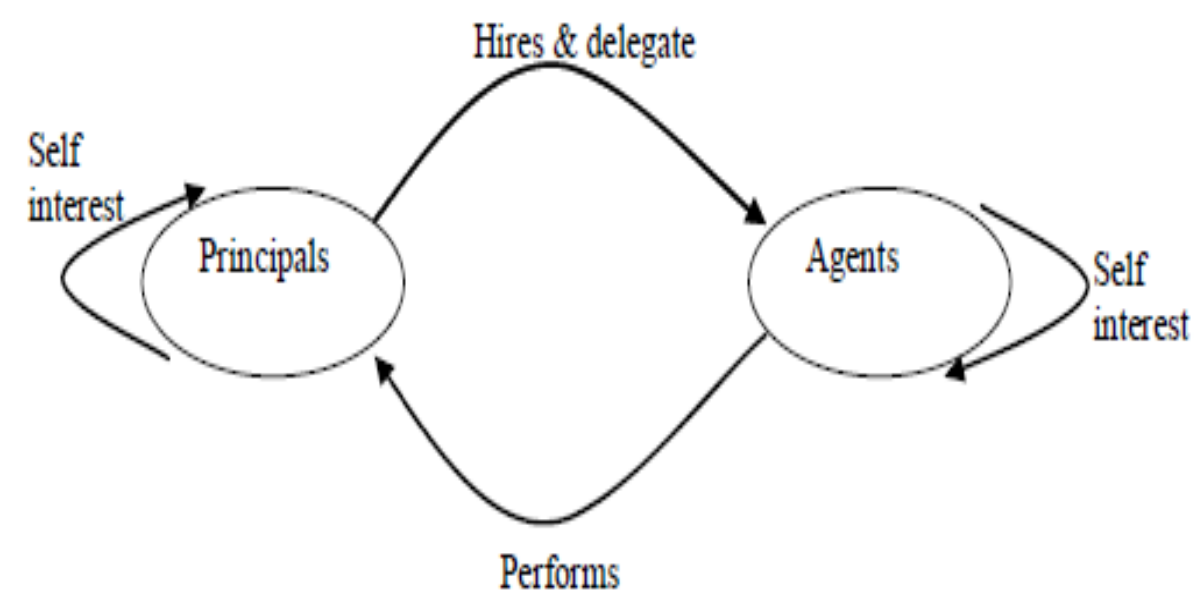

Figure 1. Stewardship Theory

Adapted from Segal and Lehrer (2012)

\section{Contributions of the Study}

This study is expected to establish the key enablers of municipal financial accountability to reduce the occurrence of irregular, unauthorised, and fruitless/wasteful expenditure. At the end of the study, a framework will be proposed which will be directed to the municipal role-players and the policy makers in establishing a sound financial management practice in the municipalities in South Africa and other developing countries who may be in the same situation. The literature study and the theoretical background be useful in providing knowledge to the academia.

Several scholars have explored the key enablers that could enhance financial accountability in a local municipal context in South Africa and otherwise. However, most of these studies are based on international countries. This study is envisaged to investigate if there is an existent of municipal financial accountability framework and to identify the key accountability enablers that could be considered by the municipal stakeholders to obtain sound audit reports in each financial year using North West province as a case study. Table 1 presents a meta-analysis undertaken to identify the key enablers for financial accountability for the purpose of this study.

Table 1. Meta-analysis of the study

\begin{tabular}{|c|c|c|c|c|c|c|c|c|}
\hline \multirow[t]{2}{*}{ Author(s) } & \multicolumn{7}{|c|}{ Constructs of the study } & \multirow[b]{2}{*}{$\begin{array}{l}\text { Consequence } \\
\text { management }\end{array}$} \\
\hline & $\begin{array}{l}\text { Policies \& } \\
\text { legislation }\end{array}$ & MPAC & $\begin{array}{c}\text { Risk } \\
\text { Management }\end{array}$ & $\begin{array}{l}\text { Internal } \\
\text { control } \\
\text { measures }\end{array}$ & Benchmarking & $\begin{array}{c}\text { Financial } \\
\text { management }\end{array}$ & $\begin{array}{l}\text { Training of } \\
\text { employees }\end{array}$ & \\
\hline Wyman (2007) & & & $\sqrt{ }$ & & & $\sqrt{ }$ & & \\
\hline $\begin{array}{l}\text { Laubscher andVan } \\
\text { Straaten (2009). }\end{array}$ & & & & $\sqrt{ }$ & $\sqrt{ }$ & & & \\
\hline Pauw et al. (2009) & $\sqrt{ }$ & $\sqrt{ }$ & & & & & & \\
\hline Ensor (2011) & & $\sqrt{ }$ & & & & & & \\
\hline Fourie et al. (2011) & & & & $\sqrt{ }$ & & $\sqrt{ }$ & & \\
\hline Gyüre (2012) & & & & $\sqrt{ }$ & $\sqrt{ }$ & & & \\
\hline Pauw et al. (2013) & & & & & & $\sqrt{ }$ & & \\
\hline Stanleigh (2016) & & & $\sqrt{ }$ & & & & & \\
\hline This study & $\sqrt{ }$ & $\sqrt{ }$ & $\sqrt{ }$ & $\sqrt{ }$ & $\sqrt{ }$ & $\sqrt{ }$ & $\sqrt{ }$ & $\sqrt{ }$ \\
\hline
\end{tabular}


Table 1 provides the meta-analysis of the study. The meta-analysis revealed that policies and legislations, Municipal Public Accounts Committee (MPAC), risk management, internal control measures, benchmarking, financial management are the key enablers to achieve municipal financial accountability. Added to these variables are training of employees and consequence management. Added to these factors are the contributions of this study which are to investigate if adequate training of municipal financial employees and consequence management could help local municipalities achieve clean audit report in each financial year in the North West province.

\section{Research Methodology}

This study was aimed at identifying the factors that can enhance financial accountability and to propose a framework to bolster financial accountability of municipalities of the North West province. The study adopted a social constructivist paradigm. The assumption of this research paradigm anchors on the belief that people try to understand the world in which they live by developing subjective meanings of their daily experiences (Creswell, 2014). The choice of this paradigm helped to understand the views of the participants, their traditional and social understandings and variations through interactions. The methodological approach adopted in this study includes the non-empirical and empirical approach. The study adopted literature reviews and document analysis as non-empirical measures to investigate the key enablers of sound municipal financial accountability.

In the empirical research, a qualitative research approach was adopted. Bryman and Bell (2015) affirm that a qualitative research focuses on the gathering of non-numerical data and reporting the findings in a narrative format. The adoption of this approach enhanced gaining an all-inclusive understanding of the phenomenon under investigation through interactions. An exploratory research design was selected to find solutions to the problem of the study. Due to the lack of adequate information regarding the reasons for municipalities not achieving financial accountability, an exploratory design was adopted to probe the role-players in the municipalities. The site for this study was selected municipalities of the North West province. With regard to participant selection, participants were selected purposively that included 36 role-players in the municipality. These role-players consists of twelve municipal accountants and municipal managers, twelve Municipal Public Account Committee (MPAC) and twelve selected councillors. In-depth interviews were adopted as the data collecting instrument and this assisted in gathering the opinions of the interviewees by asking series of organised questions. The key questions asked in the study were:

(1) What are the key enablers of sound municipal financial accountability?

(2) What recommendations could be proposed to municipal financial role-players to achieve municipal accountability?

After data collection, data were analysed using Atlas-ti software (version 8.2). In the presentation phase, pseudo-names were used to represent the names of the participants to maintain anonymity of responses. The Role Players were represented by (RL), MPAC (MP) and Councillors (CO). Themes and categories were identified and discussed subsequently by corroborating the non-empirical findings with the empirical study. Trustworthiness were maintained in the study through credibility, transferability, dependability and conformability. All the necessary ethical concepts were maintained in the study and these includes, informed consent of the interviewees, anonymity of responses, voluntary participation and exit, ensuring the safety of the participants, maintaining the gap between the interviewer and interviewee, and avoiding plagiarism in the reporting phase.

\section{Presentation and Discussion of Research Results}

This section explored the key enablers responsible to achieve financial accountability in local municipalities of the North West province. The participants were asked to indicate the factors that could enhance financial accountability, their responses are represented in the Atlas-ti network diagram in Figure 1. 


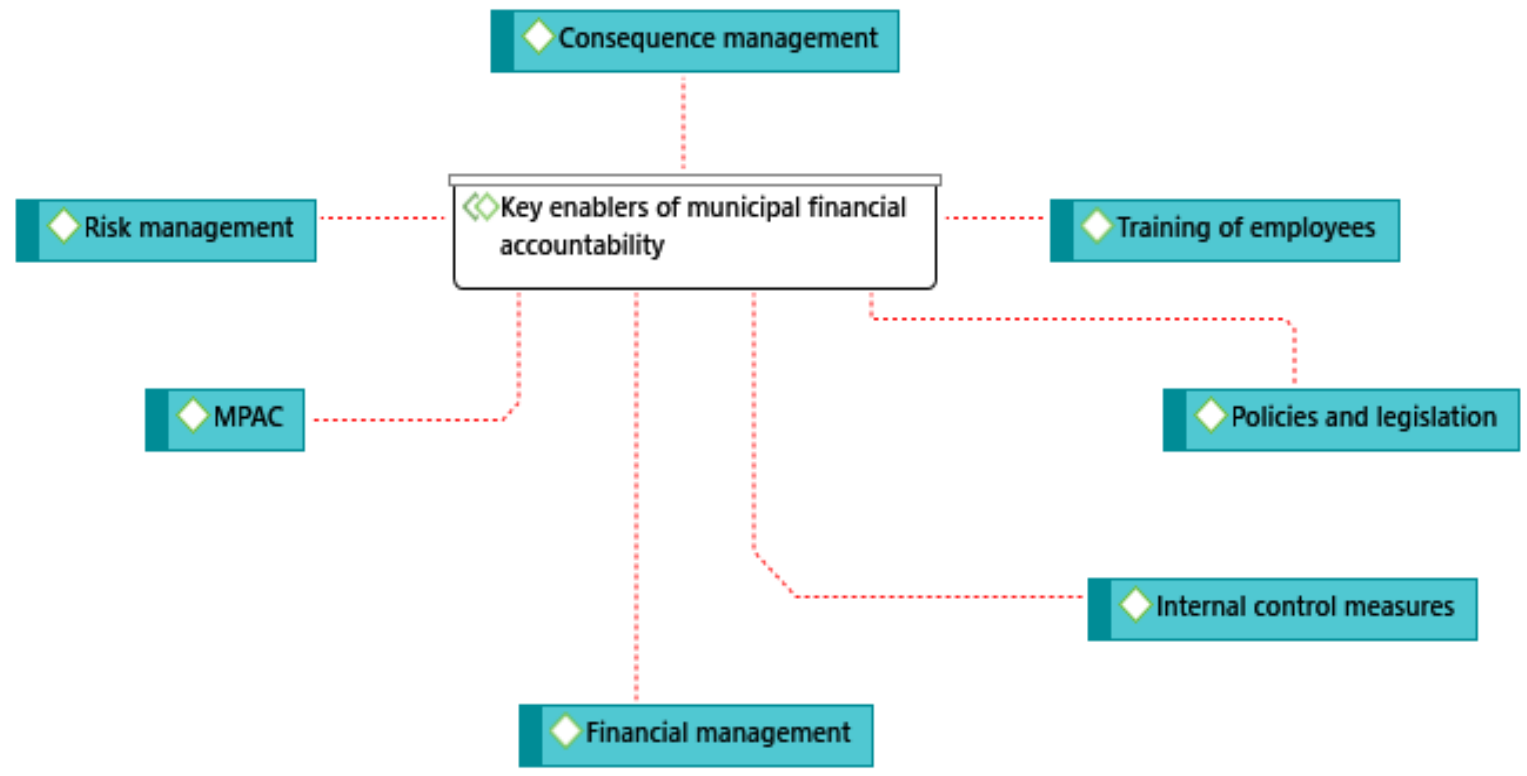

Figure 2. Key enablers of municipal financial accountability

According to Figure 2, participants indicated that the key enablers of municipal financial accountability includes training of employees, policies and legislation, internal control measures, financial management, MPAC, risk management, and consequence management. The excerpts of the participants are expounded in the subsequent delineation.

\section{(1) Policy and legislation}

Municipal policies and legislation are sets of principles made by legislature, parliament, or similar governing body with the intent of guiding actions and achieving sensible outcomes. The municipal policies and legislation included in this study are the several legislations that guides the financial practices of the municipalities in the North West province. The participants of the study declared that one of the key financial accountability enablers include the adoption of municipal policies and legislations. Most participants confirmed that the Municipal Financial Management Act (56 of 2003) is one of the main fundamental legislations they adopt. Others said that The Public Financial Management Act (1 of 1999) and the new National Treasury reform known as the Municipal Regulations on a Standard Chart of Accounts (mSCOA) helps to guide them in their various financial job specifications. The excerpts of the participants are as follows.

$\boldsymbol{R} \boldsymbol{L} 3$ affirmed "The municipal policies and legislations are the key municipal financial accountability enablers. Without keeping to the rules, policies and legislations, the municipal financial employees would not attain accountability... they will be free to do what they like".

$\boldsymbol{R} \boldsymbol{L} 4$ said "Policies and legislations controls our conduct, when you don't work according to the precepts of the financial laws...then you are out of order".

MP1 said "The main legislation that we abide with include the MFMA and the PFMA...however, there is the new policy which remains under the MFMA...this is called the Municipal Regulations on a Standard Chart of Accounts (mSCOA)... this regulation helps to guide the municipal employee in the auditing practices".

The study of Enwereji and Uwizeyimana (2019) affirms that the adoption of the municipal policies and legislations enhances achieving municipal financial accountability. The Auditor General (2019) further affirms that so many interventions, apart from the policies and legislations have been made to enhance financial accountability, such as the Hawks' national clean audit task force, which has been tasked with cleaning up municipal financial embezzlement and adjudicating tenders to ensure people receive excellent services. Some of the interventions include the Standing Committees on Public Accounts (SCOPA) which was inaugurated to guarantee that public funds were used effectively and efficiently. Despite these initiatives, no municipality in the North West province has achieved a clean audit reports. With regard to South African Constitution, Section 41(1)(c), it was stipulated that all government agencies must preserve the efficacy, openness, accountability, and coherence of all government resources. Also, Section 151(1)(a) 
mandates that municipalities ensure accountability in all spheres of governance.

The principal legislation controlling the financial activities of municipalities in South Africa include the Municipal Finance Management Act (56 of 2003) and the Public Financial Management Act (1 of 1999). While the MFMA is in charge of maintaining the municipal information system, accounting, reporting, the roles of municipal managers, accountants, internal auditors, councillors, and treasurers, the PFMA ensures that municipal finance management is efficient and transparent, disciplinary action for financial deviations, preserving financial records, and reporting financial records at the end of each fiscal year (Enwereji \& Uwizeyimana, 2019). Other municipal financial policies and legislations that were pointed out by Enwereji and Uwizeyimana (2019) as a source to achieve financial accountability include the Municipal Structures Act (117 of 1998), the Municipal Systems Act (32 of 2000), the Public Finance Management Act (1 of 1999), Municipal Property Rates Act (6 of 2004), National Credit Act (34 of 2005), Municipal Fiscal Powers and Functions Act (12 of 2007), and the Auditor-General Act (12 of 1995).

\section{(2) Internal Control}

Internal control refers to a process to ensure that reliable and authentic financial information is reported and also that information about inefficiency and effectiveness regarding the operations of an organisation comply with relevant regulations and laws. The participants in the study confirmed that internal control is one of the key enablers to achieving sound municipal financial accountability. Some of the participants indicated that internal control helps as a preventive, detective, and corrective tool. Few participants confirmed that internal control measure enhances accountability as it investigate deviations in the accounting information. Others confirmed that the internal control department measures if the municipal role-players follows the rules, laws, policies and legislations in handling municipal finance. The excerpts from the participants are as follows.

$\boldsymbol{R L 1}$ said "Internal control helps in achieving municipal financial accountability".

$\boldsymbol{R} \mathbf{2}$ said "Without internal control, we cannot determine if the accounting process follows due process".

$\boldsymbol{R} \boldsymbol{L} 7$ confirms "We use internal control to know if the procedures follows the municipal policies and legislations".

MP7 said "The application of internal control in the municipalities helps as a preventive, detective and corrective tool".

Finally CO5 affirmed "Internal control helps to investigate if the deviations in the municipal accounting information.... without internal control, the municipal financial employees and politicians would be careless in handling financial resources".

The findings of Ncgobo and Malefane (2017) view internal control as a process that guarantees obtaining reliable, effective and efficient financial information and ensures that organisation comply with relevant regulations and laws. Ncgobo and Malefane (2017) argues that creating a foundation for effective financial processes is directly connected to establishing well-defined financial accountability structure. However, Omondi (2021) points out that issues associated to internal control measures are due to the inability of the municipal role-players to maintain a stable control climate, inconsistency in governance, and lack of capacity to respond as required. In the view of Huefner (2011), the lack of facilitating internal control reduces the monitoring of the budgets' contents which results in the fraudulent and irregular spending, waste, loss or ineffective use of the municipality's resources, which may escalate the municipal tax burden. Furthermore, Bruwer (2016) affirms that the financial threats have escalated to an unbearable level that they are not only a threat to local communities but also a threat to the economy as a whole but the internal control system could be used to facilitate reliable and effective operating processes, and delivering sustainable financial service. In order to be accountable to the public, local municipalities must devise an efficient internal financial control system (Enwereji \& Uwizeyimana (2019). The internal control division has a responsibility to ensure that the public's financial transactions are reported and presented competently (Omondi, 2021). Mtantato (2021) argues that managers should enforce a sound internal management structure and sound governance in their different areas of responsibility, because it is claimed that improved transparency is important for both good government and effective service delivery. In this case, Niroula and Gyawali (2021) recommend that internal control as a mechanism should be implemented by municipal administration in order to provide a fair assurance of the achievement of internal finance regulation, effective governance and transparency, reporting reliability, organizational efficiency, internal control legislation.

\section{(3) Financial Management}

Financial management refers to a process of planning, organizing, regulating, and monitoring financial resources of the organisation to meet the goals and objectives of an organization. It is an ideal practice for controlling an organization's 
financial activities, such as fund procurement, fund utilization, accounting, payments, risk assessment, and anything else involving finance. The participants of the study concurred that adequate financial management is one of the key enablers of municipal financial accountability. Some participants of the study concurred municipal financial management ensures that culprits are accountable to oversight structures. Most participants stated that budgeting as a part of financial management helps to estimate the expected income and expenditures of the organisation. The excerpts of the participants are as follows.

$\boldsymbol{R L 1}$ said "Adequate financial management is needed in the municipalities...it is one of the key enablers to achieving sound financial accountability. Financial management should not just be a role of the Budget and Treasury Office, every municipal official must understand financial management including issues of budget, audit, etc.

$\boldsymbol{R} \boldsymbol{L 1}$ said "Yes, adequate financial management enables the municipalities to be proactive in dealing with non-complying to norms and standards".

CO5 said "Adequate financial management does enhance financial accountability at the institution, because of sufficient systems, controls, policies and processes being put into place".

CO8 said "Financial management exposes culprits who commit financial fraud to the applicable oversight committees".

The findings in this section conforms to the study of Brigham and Houston (2021) who confirms that efficient financial management strategies are very paramount in every public organisation. In this direction, Pauw et al. (2013) postulates the three basic principles of financial management as to why, what and how financial capital can be efficiently actualized. In the view of Banerjee (2015), financial management is a practice where funds are mobilized and managed for the organisation and this helps to make investment decisions to ascertain that the investment is profitable or worth committing resource. Enwereji and Uwizeyimana (2019) affirms that most municipalities in the North West province have been unable to achieve financial accountability due to their inability to facilitate equitable financial management. In the view of Pauw et al. (2013), financial management is an organization's most sensitive section as it improves the option of financial decisions, acquisitions and dividend payment, also profit maximization and welfare of the citizens are based on the intelligent financial decision and commitment by the municipality's top management.

Jovanović and Vašiček (2021) and Fourie et al. (2011) state that budgeting as a part of financial management provides a systematic financial planning strategy and detailed guide to restricting financial management procurement activities. Also, Ofojebe and Amaikwu (2021) postulates that the municipal budget contains the requisite development plans that would be implemented by municipalities to achieve their goals. Concerning accounting, Fourie (2014) attests that it facilitates creating a financial report to assess the municipality's financial status and to know improvements in cash receipts and expenditure over time. The auditor reviews the financial report prepared by the municipal accountant to ensure that the material complies with the municipality's policy (Fourie, 2014). Auditing helps expose fraud, corruption, growth, hazard and other confidential details in the Financial Report. The 2003 Municipal Financial Management Act, No 56, states that at the end of each fiscal year, the auditor general is responsible for auditing the local financial reports. Sikhakane and Reddy (2011) affirm that annual report as a part of financial management gathers sufficient information on receipt of funds from each annual source and total municipal financial management expenditure and these are registered and published annually, monthly or quarterly, and submitted for review to management.

\section{(4) Municipal Public Account Committee (MPAC)}

The Municipal Public Accounts Committee (MPAC) was established in terms of Section 79 of the Municipal Structures Act (117 of 1998). The purpose of establishing the MPAC was to perform an oversight function on behalf of the Council over the executive functionaries of the Council to the extent set out herein. The participants of the study confirmed that the establishment of the Municipal Public Accounts Committee is a key enabler of municipal financial accountability. Participants concurred that it is the responsibility of MPAC to make recommendations to the committee regarding Unauthorised, Irregular and Wasteful expenditures. Others opines that consequence management is applied by the decision of MPAC to reduce fraud. Direct excerpts from the participants are as follows:

RL5, RL10, MP2, MP3, MP6, CO1 confirmed "The Municipal Public Accounts Committee is one of the key enablers of municipal financial accountability".

$\boldsymbol{R L 4}$ said "The role of MPAC is critical because it plays oversight on finance matters, also MPAC is constituted by Councillors with relevant knowledge, skills, and experience to deal with financial matters". 
MP2 said "MPAC is concerned with strict implementation of the framework or available legislative measures and continuous review and evaluation of the framework in order to improve areas of weakness".

CO7 affirmed "MPAC implements consequence management without fear or favour thus strengthening Internal Audit Units, Audit Committees and Financial Misconduct Disciplinary Boards".

CO4 said "MPAC is an oversight committee of Council that ensures that the finances of a Municipality are not abused, also ensures that consequence management applies to any transgressor and ensure that SAPS investigates where necessary".

According to Section 151(1) (a) of the Constitution, all local governments must ensure credible, democratic and accountable government for local communities, including efficient and economic use of public financial resources. This was confirmed by Kraai, Holtzhausen and Malan (2017), who state that the aim of the policy is to promote oversight functions and accountability by allocating functions and powers to both legislative and executive authority in their municipality. In the view of Thornhill and Cloete (2014), MPAC is a committee that promotes oversight and scrutiny within municipalities to provide for the critical essentials, instruments and practices that are central in aiding municipal councils to advance societal development and financial growth. According to Ekurhuleni Metropolitan Municipality Councillors Handbook (2011), oversight function of the MPAC include an analysis of the executive business conducts to ensure they are in tune with legally provided principles of governance. According Fourie and Malan (2020) "Public procurement which MPAC investigates refers to all kinds of acquisitions of public goods and services". Oluka (2013) posits in his study that oversights conducted on public procurement in Uganda helps to achieve accountability. In this regard, Fourie and Malan (2020) posit that oversight functions should be conducted in the municipalities to achieve accountability. In conclusion, Enwereji and Uwizeyimana (2019) confirmed that MPAC remains a key municipal financial accountability enabler, also the municipalities should implement the recommendations of MPAC to achieve sound financial accountability.

\section{(5) Risk management}

Risk management is the process of identifying, evaluating, and prioritizing risks, then deploying resources in a coordinated and cost-effective manner to reduce the likelihood and impact of unfortunate events or to optimize the realization of opportunities. It is also a process of discovering, assessing, and controlling threats to an organization's capital and profitability. The participants of the study concurred that risk management is a key enabler of municipal financial accountability. The participants further maintained that the facilitation of risk management in the municipalities helps to identify potential risks which have impacts the strategic objectives of the institution. The excerpts of the participants are as follows:

$\boldsymbol{R} \boldsymbol{L} 2$ said "Risk management is a key enabler to achieve municipal financial accountability".

$\boldsymbol{R} \boldsymbol{L} 8$ said "To achieve financial accountability, it is important to identify risks and mitigate the risks before the external auditors can identify those risks...in my municipality at the moment, there is no unit that deals with risk management department and this results in the mismanagement of financial resources".

$\boldsymbol{R} \boldsymbol{L} 3$ said "Effective risk management goes beyond having adequate insurance policies in place, risk management is a core management discipline that comes into play every time one makes decision that affects the organisation, therefore, risk management plays a key role as it identifies the risk areas such as where the system might susceptible to fraud".

MP5 said "Risk management is key control that help monitor risks on the post audit action plan (PAAP)".

MP7 said "Risk management helps to enhance financial accountability by identifying risks within the organization and develop controls to mitigate those risks".

CO12 concluded "Risk management is critical in the municipalities as it enhances financial accountability because it identifies potential risks which have impacts the strategic objectives of the institution".

Risk management to the constructive monitoring of future organizational incidents or threats, it also involves tracking market and non-market long-range risks, understanding their adverse impact on the business environment, and managerial responses to reduce risk exposure (OECD, 2014). Risk management continues to be a major issue for firms seeking to expand and succeed in the business climate, NT (2020) affirms that municipalities should identify risks in order to gain a competitive advantage, and then find a way to reduce the risks that tend to impede efficiency. Risk management supports firms in making detailed financial decisions and Stanleigh (2016) notes that achieving optimum result requires that the municipalities identify and evaluate the required risks and returns. Applying aspects of risk management has assisted municipalities to reduce irregular, unwanted and fruitless or wasteful expenditures (NT, 
2020). Adequate risk management promotes transparency and offers a succinct overview of risks that can be resolved by the organisation, thus allowing them to make informed decisions. Good risk management underlines the handling of risks according to the Association of Certified Chartered Accountants (2011), it also help municipalities understand the possible risk factors that hold back organisational growth and to achieve accountability (Enwereji \& Uwizeyimana, 2019).

\section{(6) Training of financial employees}

In the field of human resource development, training is concerned with the development of employees' skills to a desirable standard. Training is a powerful tool for putting a person in a position where they can accomplish their work correctly, efficiently, and with integrity. It helps in the improvement of an employee's knowledge and skills in order for them to do a specific job. According to the findings from the semi-structured interviews, the participants concurred that training of municipal financial officials is one of the key enablers of municipal financial accountability. They affirmed that training of officials is very paramount to improve them to obtain the best performance. However, some participants regretted that some municipal employees lack adequate skills to handle municipal finance. Others alleged that some of the municipal financial officers do not have the basic qualifications to work in the municipality but were offered the jobs through nepotism. Some participants confirmed that the municipalities do not facilitate adequate trainings on how to improve financial management for municipal financial employees. Some excerpts from the participants are as follows:

MP8 said "The process of training remains a key enabler of sound municipal financial accountability... when the financial officials are adequately trained... it helps them to perform exceedingly".

CO4 said "The problem we have in achieving clean audit report is that most municipal financial workers do not have the desired skills to work in the various job specifications.... they happen to hired by chance and this really affect municipal financial accountability".

MP6 said "I am sure that some municipal financial employees do not have the basic qualifications to do their jobs but got the job through the act of nepotism...some political office holders sometimes induce employment opportunities which affect the financial health of the municipality".

CO7 said "Our municipality do not facilitate training ....there should be training opportunities in the municipalities in every quarter to ensure that the skills of the financial workers are improved".

The findings of Elnaga and Imran (2013) affirm that training is a process through which employees' skills are developed. In the same direction, Jalali, Baghban, and Abedi (2011) opine that training consists of planned programme designed to improve performance at the individual, group, and /or organizational levels. This implies that training depict a transmogrification in knowledge, skills, attitude, and/or social behavior. McNamara (2021) further affirm that training is human resource tool for human development with immense potential for leadership development, organization of people, formation of self-help groups, mobilization of people and resources, empowerment of resource-poor rural groups, and entrepreneurship development, among others, which are regarded as important components of human resources development. McNamara (2021) further declares that training of municipal employees enhances their capacity to handle municipal finances effectively. Other advantages of training in the municipal sphere includes job satisfaction, building the morale among employees, intensifies the level of employee motivation in the workplace, provides more opportunities for increased efficiencies in processes, resulting in financial gain, and increases capabilities to adopt new technologies and methods. With regard to these findings, the municipalities of the North West province should endeavor to train their financial employees adequately to equip them with the desired knowledge to handle financial matters of the municipality as this will eliminate the financial mismanagement such as irregular expenditure, fruitless and unwanted expenditure. It will also enhance obtaining clean audit report at each financial year.

\section{(7) Consequence management}

An internal system or procedure that specifies an organization's approach to managing compliance and mitigating compliance risk is known as a consequence management, sometimes known as a compliance policy. Management measures taken to sustain or restore vital services, as well as repair and reduce faults resulting from performance, are referred to as consequence management. The constant emphasis on openness and the consequences of non-compliance is a social threat in today's society and deserves to be addressed. Consequence management was viewed by the participants as a key enabler of municipal financial accountability. The participants of the study concurred that the inability to apply consequence management in the municipalities has resulted in poor financial accountability. The excerpts of the participants are as follows: 
RL6 said "Consequence management enhances municipal financial accountability...when there is punishment on deviations... both municipal financial workers and councillors would be careful in spending financial resources".

MP3 said "Consequence management investigates the financial records of the municipality thereby making it difficult for culprits to escape”.

MP12 affirm "The problem we have in the municipalities is that actions are not adequately taken on the culprits...the law enforcement agents should ensure that legal action are taken against the culprits without fear or favour".

CO1 said "When reasonable action is taken against a culprit, then...others will learn from it”.

The National Treasury (2018) points out that there is a need that local municipalities be accountable to the provincial or national government to guarantee that residents receive their dividends of democracy. The Auditor General (2019) further stipulates that municipalities in South Africa have many strategic tools available in the battle against corruption and maladministration, and their attempts to improve strategic and personal credibility, following 25 years of municipal government in a growing democratic phase have not been proved effective. Regarding the anti-corruption measures adopted, the local municipalities' ability to implement anti-corruption norms on the administrative and political leadership have remained unsuccessful (NT, 2018). This is due to the degree to which bureaucracy follows certain requirements. Auditor-General have emphasized that the lack of compliance with legislation is very weak and the inability to impose penalties on corruption. Enwereji and Uwizeyimana (2019) noted that there is a severe financial transgression by the political and administrative leaders, yet no consequence management is applied. It has been confirmed by COGTA (2018) that municipalities are the targets for transgressors who have confidence that the mechanisms of municipalities to manage consequence are poor, while their methodologies of detection are ineffective and can be exploited. On this note, the Municipal Financial Management Act Section 173 assert that any financial offence committed by any administrator should be reported to SAPS immediately for investigations. With regard to penalties, Section 174 of same MFMA states that a public officer is liable on conviction of an offence in terms of section 173 to imprisonment for a period not exceeding five years or to an appropriate fine determined in terms of applicable legislation.

\section{Municipal Financial Accountability Framework}

The introduction of this study revealed that the local municipalities of the North West province have been unable to achieve clean audit reports over the years due to the occurrence of unauthorised, irregular and wasteful expenditures. The study conducted a wide literature review and identified eight key enablers of financial accountability. These factors include policies and legislation, the oversight functions of MPAC, risk management, financial management, internal control and benchmarking. Added to these factors are training of municipal employees and consequent management. However, the empirical study revealed that benchmarking is a tool for comparison which leads to the growth of the organisation and do not necessarily facilitate financial accountability. All other factors tested positive due to the responses as obtained from the participants and deemed relevant to enhance municipal financial accountability. Figure 3 presents the municipal financial accountability framework. 


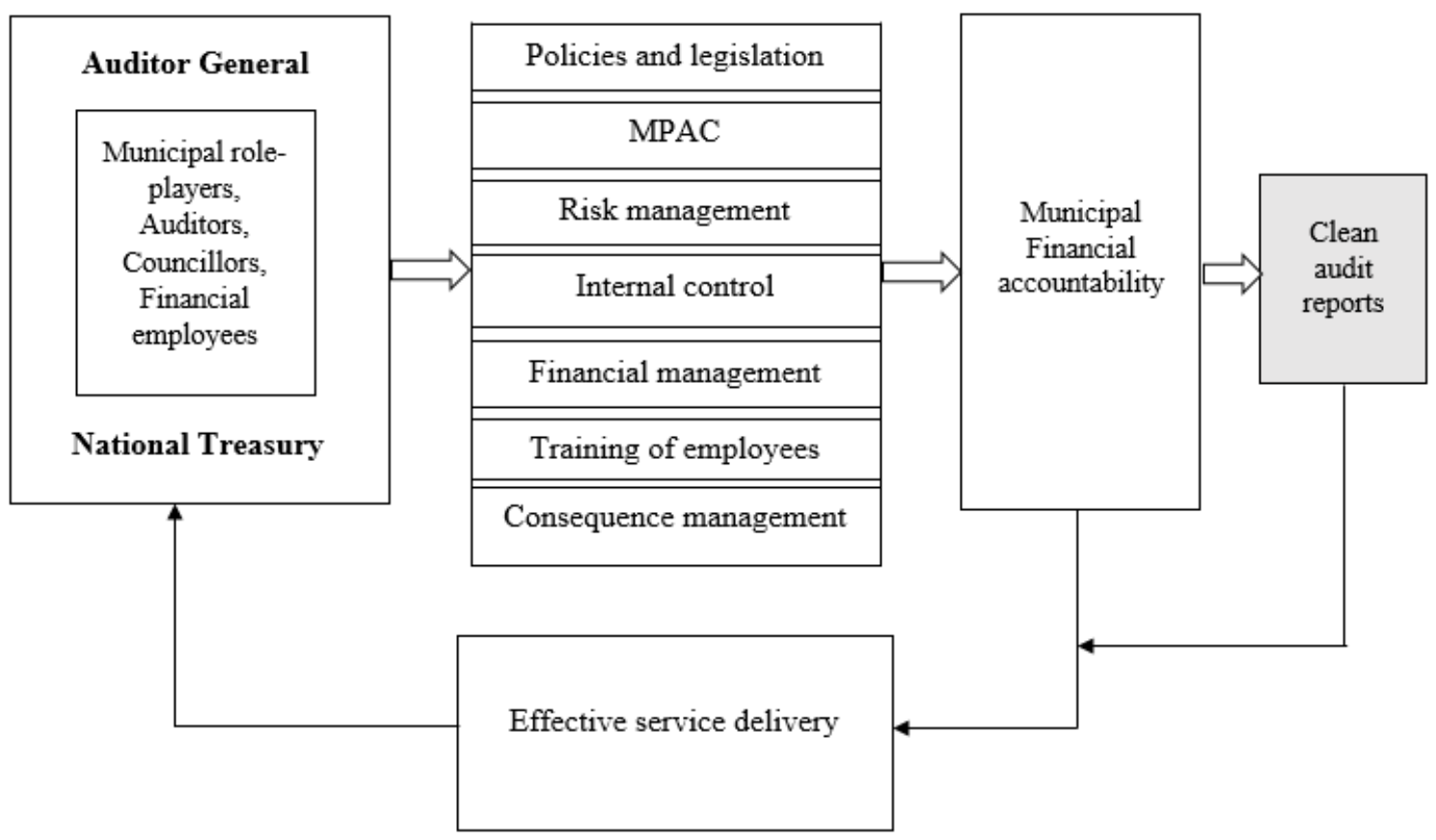

Figure 3. Municipal financial accountability framework

To achieve municipal financial accountability, Figure 3 was formulated to depict that municipal role-players, accountants, councillors, and all the financial employees (who are guided by the Auditor General and the National Treasury) should observe the municipal financial policies and legislation in handling the financial procedures of the municipalities. The Municipal Public Account Committee should facilitate their oversight functions in all the financial reports presented by the municipalities. Other factors as presented in Figure 3 include the facilitation of risk management, financial management, training of employees, and consequence management. The framework further portrays that adopting these key enablers by the role-players (and others) would enhance municipal financial accountability which will attract clean audit reports. The diagram also depict the achieving financial accountability and clean audit reports would induce equitable service delivery in all the municipalities. Having presented the financial accountability framework, the next section presents the recommendations of the study.

\subsection{Contributions to the Body of Knowledge}

This study identified the key enablers of municipal financial accountability. Concerning this objective, an empirical research was done and it was revealed that these include policies and legislation, internal control measures, financial management, MPAC, risk management, and training of municipal financial employees. Additional factor include consequence management which tested positive in the empirical study and considered effective in enhancing municipal financial accountability. The contribution of the study includes two factors which are consequence management and training of municipal financial employees.

\subsubsection{Consequence Management}

Management measures taken to sustain or restore vital services, as well as repair and reduce faults resulting from performance, are referred to as consequence management. The constant emphasis on openness and the consequences of non-compliance is a social threat in today's society and deserves to be addressed. Chapter three noted that the recurrent emphasis on transparency and the implications of non-compliance is a social menace in the society today and response to corruption between national and private leadership. Due to the intensity of crime and municipal financial mismanagement over the years, there is a need to establish accountability in the local municipal sphere and to facilitate consequence on default. The findings obtained in the study revealed that consequence management is a key enabler to achieving a sound municipal financial accountability, unfortunately participants voiced that it is not applied effectively due to nepotism and corruption. The participants of the study concurred that the inability to apply consequence management in the municipalities has resulted in poor financial accountability. Furthermore, the participants noted that municipal financial employees and politicians would desist from money laundering, fraud, and mismanagement of 
financial resources if the culprits receive proper judgement or desired punishment for their deviations. This factor was deemed effective as a key enabler to achieve municipal financial accountability, hence included to propose the framework of this study.

\subsubsection{Training of Municipal Financial Employees as an Important Factor}

Training refers to the methods of improving the knowledge, competencies, and skills of individuals or groups. Professional training is typically provided outside of the workplace and may include getting certification or specific understanding about a profession in order to do a job in a more sophisticated way. Training can be offered in the form of seminars or conferences and handled by professionals to increase the employees' skills. The literature review revealed that training opportunities assist the municipal financial employees by equipping them with management skills that they need on their daily financial job specifications. In the empirical study, the participants affirmed that training is a key enabler of municipal financial accountability. It was noted that it is very important that municipalities facilitate training programmes consistently to enhance the skills of the employees. However, it was noted that some municipal financial workers do not have the competent skills to handle financial transactions, thus limiting them to facilitate their duties effectively. Regarding basic qualification, the biographical details of the employees revealed that most of the participants are Matric holders, also the participants in the empirical investigation stated that the municipal financial officers do not have the requisite qualifications to handle municipal financial tasks. Regarding the qualifications, an allegation was made that most financial workers were employed based on nepotism of the political lords. With regard to the findings in this section, the study proposes that the municipalities should adequately facilitate trainings to improve financial management for municipal financial employees.

\subsubsection{Theoretical Contributions}

The Stewardship theory adopted in this study suggests that managers are answerable to resource owners, ensuring effectiveness, profiting resource utilization, and securing success and sustainability. To guarantee sustainability in the local municipal context, municipal financial report must be handled properly, as it acts as a good means of measuring management stewardship by the owners. The agents safeguards and exploits shareholders wealth through selfless performance and are fulfilled and driven when success is accomplished in the organisation. The stewardship theory stresses that both the principals and the agents should act autonomously to attain success. This implies that the stewards should by transparent, dedicated, accountable and diligent while the employers should always corporate and collaborate with them to achieve desired goals. In this direction, credible financial reports should be provided and kept open for scrutiny to avoid suspicions and to close the existing communication gaps. Therefore, the municipal role-players, Municipal Public Accounts Committee, the Accountants and the Politicians should always work together, communicate effectively and agree together in an endeavour to achieve the service provision mandates of the municipality.

\section{Recommendations of the Study}

Based on the framework as presented in Figure 3, the recommendations of the study are as follows:

\subsection{Policies and Legislation}

The municipal role-players should always abide with the municipal bye laws, policies, and all municipal legislations guiding municipal finance in all the municipalities. Standing Committees on Public Accounts (SCOPA) should always guarantee effective oversights on the use of public funds. The Municipal Finance Management Act (56 of 2003), Public Financial Management Act (1 of 1999), Municipal Structures Act (117 of 1998), the Municipal Systems Act (32 of 2000), Municipal Property Rates Act (6 of 2004), National Credit Act (34 of 2005), Municipal Fiscal Powers and Functions Act (12 of 2007), and the Auditor-General Act (12 of 1995), the directives from the Auditor General and should be applied or consulted when making municipal financial decisions.

\subsection{Internal Control}

The municipalities should always facilitate internal control measures to enhance financial accountability. The adoption of internal control will expose deviations on policies, laws, rules and legislations guiding municipal financial management. The role-players should adopt internal control to monitor budgets to reduce the rate of irregular, unauthorized and wasteful expenditures. The municipalities should also facilitate the processes of internal control such as creation of objectives, setting of standards, performance measurement; performance assessment, comparison of organizational performance with established standards and goals, analyzing cause of deviations, determining appropriate managerial actions to take, and continuous re-evaluation. The risk management department should ensure effective communication when facilitating preventative, detective and corrective internal controls. 


\subsection{Financial Management}

The municipalities should facilitate effective financial management to ensure accountability in the municipal sphere, also it will address why, what and how financial resources can be efficiently actualized. The implementation of effective budgeting as an aspect of financial management will provide a systematic financial planning strategy and detailed guide to restricting financial management procurement activities. Budgetary control should assist the management to set targets, measure these goals against real results, and guide employees to comply with the laws to achieve the objectives. Financial reporting will ensure that the material complies with the municipality's policy while auditing will assist in exposing fraud, corruption, growth, hazard and other irregularities in the Financial Report

\subsection{Municipal Public Account Committee (MPAC)}

To achieve financial accountability, the Municipal Public Account Committee should endeavour to facilitate their oversight functions on the financial activities of the municipalities and this should be done without fear or favour. MPAC should always be concerned with strict implementation of the framework or available legislative measures and continue reviewing and evaluate the available financial frameworks in order to improve areas of weakness. Recommendations should always be done by MPAC to the municipalities to make amendments or improve in their various financial job specifications. Municipal Public Account Committee should review budget implementation plans and annual reports, oversight on service delivery, monitor spending patterns, and implementation of bye-laws. MPAC must also facilitate stakeholder involvement such as community engagements in an endeavor to enhance financial accountability.

\subsection{Risk Management}

Equitable risk management should be conducted in all municipalities to achieve financial accountability. Adopting risk management will help identify, evaluate, and prioritize potential risks, then deploying resources to reduce the likelihood and impact of unfortunate events. Municipalities should always make plan of action to improve the institution's risk management maturity and a focus on the prevention of fraud and corruption as this would increase awareness, transparent evaluations and sound mitigation of risks facing the institution. The municipalities should endeavor to identification of risk, conduct analysis of the causing factors; analyse the likelihood of occurrence; prioritize the identified risks; formulate and implement the response strategy, and ensure continuous evaluation of the effects of the response.

\subsection{Training of Financial Employees}

The municipalities should always facilitate training for municipal financial employees to improve their skills to perform effectively in their duties. The participants of the study noted that some employees are not qualified or lack adequate skills to handle municipal finance, the municipalities should ensure that competent personnel are hired, also appointments should not be based on favouritism of nepotism. Screening should be facilitated in all the municipalities to identify those who are not capable to handle municipal finance, after the identification of unskilled staff, training should be facilitated to enhance their skills as this as this will eliminate the financial mismanagement such as irregular expenditure, fruitless and unwanted expenditure and enhance obtaining clean audit report at each financial year.

\subsection{Consequence Management}

The municipalities should ensure that consequence management is facilitated as this would enhance effective financial accountability. The Municipal Public Accounts Committee should investigate the financial records of the municipality. Also legal actions should be taken against the role-players that are found guilty of corruption or laundering. Also, judgement should not be delayed to apply legal actions on culprits as it is believed that 'justice delayed is justice denied'.

\section{Conclusion of the Study}

This study investigated the factors that can enhance financial accountability of local municipalities in the North West province. This study was motivated due to the inability of the local municipalities to achieve clean audit reports over the years. This has hampered the provision of service delivers as constitutionally mandated as municipal financial resources are mismanaged. The aim of this study was to propose a financial accountability framework that would serve as a guide to al local municipalities in handling municipal financial resources. The study adopted a qualitative research approach which was guided by the constructivist research paradigm. Semi-structured interviews were used to collect data from the selected thirty five participants who participated in the study. The study selected eight local municipalities from four district municipalities of the North West province.

Findings from the study indicated that due to mismanagement of municipal financial resources, the attainment of a 
clean audit report has not been possible by the municipalities of the North West province. In this regard, the researcher investigated the key enablers of municipal financial accountability in the non-empirical investigation. It was revealed that the facilitation of policies and legislation, the activities of the Municipal Public Accounts Committee, risk management, benchmarking, internal control, financial management, training of financial employees and consequence management could enhance municipal financial accountability. These factors were investigated in the empirical study and it was discovered that all are key enablers towards achieving financial accountability except benchmarking which was regarded as a growth tool.

This study only investigated how municipal financial accountability could be upheld in the North West province of South Africa. The results could also be applied to other provinces of the country, as well as other provinces in other developing countries that may face same situations. Also, the results as presented in this study may not be generalised due to diverse administrative measures and managerial practices of municipalities in South Africa and otherwise. The study concludes that the mismanagement of municipal financial resources which results in the inability to achieve a clean audit report by the municipalities in the North West province could be resolved if the recommendations of this study could be put into practice. Above all, the municipal financial employees should always collaborate and ensure that matters are being resolved before it is too late, as this would end the era of financial mismanagement. As noted in chapter one of this study, local municipalities in South Africa can improve their proposition for effective service delivery, good maintenance culture, and economic development if they entrench effective financial management practice.

\section{References}

Association of Chartered Certified Accountants (ACCA) and Securities Investors Association Singapore (SIAS). (2011). The Value of Audit: Views from Retail (Private) Investors, July. Retrieved 15th Sept. 2021, from www2.accaglobal.com/pdfs/international/singapore/VOAPAC

Auditor General. (2019). Report of the Auditor General to the North West Province. Pretoria: Government Printer.

Banerjee, B. (2015). Fundamentals of financial management (2nd ed.). New Delhi: PHI Learning

Brigham, E. F., \& Houston, J. F. (2021). Fundamentals of financial management. Cengage Learning.

Bruwer, J. P. (2016). The relationship (s) between the managerial conduct and the internal control activities of South African fast moving consumer goods SMMEs. Doctoral dissertation, Cape Peninsula University of Technology. https://doi.org/10.4102/sajems.v20i1.1569

Bryman, A., \& Bell, E. (2015). Business research methods. USA: Oxford University Press.

Caers, R., Du Bois, C., Jegers, M., De Gieter, S., Shepers, C., \& Pepermans, R. (2006). Principal-agent relationships on the stewardship-agency axis. Non-profit Management \& Leadership, 17(1), 25-34. https://doi.org/10.1002/nml.129

Cossin, D., Ong, B. H., \& Coughlan, S. (2015). A practical perspective: Stewardship. Fostering responsible long-term wealth creation. IMD Global Board Center, pp. 1-40.

Creswell, J. W. (2014). Research Design: Qualitative, quantitative, and mixed methods approaches (4th ed.). CA: Sage Publications.

Elnaga, A., \& Imran, A. (2013). The effect of training on employee performance. European Journal of Business and Management, 5(4), 137-147.

Enwereji, P. C., \& Uwizeyimana, D. (2019, September). Exploring the key factors that can enhance municipal financial accountability in Africa: experience from South Africa. African Renaissance, 16(Special Issue 3), 143-165. https://doi.org/10.31920/2516-5305/2019/SIn3a10

Fourie, D. (2014). Improving budgeting and financial management. Public administration and management in South Africa: A developmental perspective, 270-294.

Fourie, D., \& Malan, C. (2020). Public procurement in the South African economy: Addressing the systemic issues. Sustainability, 12, 8692. https://doi.org/10.3390/su12208692

Fourie, M., Opperman, L., Scott, D., \& Kumar, K. (2011). Municipal Finance and Accounting (2nd ed.). SA: Van Shaik Publishers.

Hannafey, F. T., \& Vitulano, L. A. (2013). Ethics and executive coaching: An agency theory approach. Journal of Business Ethics, 115(3), 599-603. https://doi.org/10.1007/s10551-012-1442-z 
Huefner, R. J. (2011). Internal control weaknesses in local government. The CPA Journal, 81(7), 20.

Jalali, G., Baghban, I., \& Abedi, M. R. (2011). Tthe effect of meaning-making training at work in career happiness of Isfahan University employee.

Jovanović, T., \& Vašiček, V. (2021). The role and application of accounting and budgeting information in government financial management process - a qualitative study in Slovenia. Public Money \& Management, 41(2), 99-106. https://doi.org/10.1080/09540962.2020.1724405

Kraai, S., Holtzhausen, N., \& Malan, L. (2017). Oversight Mechanisms in Local Government: A Case of Ekurhuleni Metropolitan Municipality in South Africa. African Journal of Public Affairs, 9(6), 59-72.

Lopes, H. (2012). Individuals, persons and agency theory: contrasted views on social interactions at work. Working Paper. https://doi.org/10.7749/dinamiacet-iul.wp.2014.04

McNamara, C. (2021). Employee training and development: Reasons and benefits. Retrieved 12th October 2021, from https://managementhelp.org/training/basics/reasons-for-training.htm

Ncgobo, P., \& Malefane, S. R. (2017). Internal controls, governance and audit outcomes-case of a South African municipality. African Journal of Public Affairs, 9(5), 74-89.

Ngozo, T., \& Mtantato, S. (2021). Leadership, management and governance for sustainable public service delivery. $\begin{array}{llll}\text { Retrieved 30th June } & \text { 2021, from }\end{array}$ https://ffc.co.za/wp-content/uploads/2021/08/Chapter-10-Leadership-management-and-governance-for-sustaina ble-public-service-delivery.pdf

Niroula, B., \& Gyawali, A. (2021). Internal Control Systems in Nepal: A Case of Nepal Telecom. Jambura Science of Management, 3(2), 99-113. https://doi.org/10.37479/jsm.v3i2.10447

OECD. (2014). Corporate Governance: Risk management and corporate governance. OECD Publishing. https://doi.org/10.1787/9789264208636-en

Ofojebe, W., \& Amaikwu, J. O. (2021). Comparative analysis of budgeting practices of principals for enhacing financial management in public and private secondary schools in anambra state, nigeria. UNIZIK Journal of Educational Research and Policy Studies, 2, 151-165.

Oluka, P. N. (2013). Public Procurement Reforms: Issues and Challenges: The case of Uganda. In Presentation at the CIPS Pan African Conference 21-22 at National Theatre, Ghana.

Omondi, M. A. (2021). Internal Control Systems on Financial Accountability in National Public Secondary Schools in Kenya. Doctoral dissertation, JKUAT-COHRED.

Pauw, J. C., Woods, G., Van der Linde, G. J. A., Fourie, D., \& Visser, C. B. (2013). Managing public money: systems from the South (2nd ed.). Johannesburg: Heinemann.

Republic of South Africa. (1995). Auditor-General Act. Pretoria: Government Printer.

Republic of South Africa. (1996). Constitution of the Republic of South Africa. Pretoria: Government Printers.

Republic of South Africa. (1998). Municipal Structures Act, 1998 (Act 117 of 1998). Pretoria: Government Printers: Pretoria

Republic of South Africa. (1999). Public Finance Management Act. Pretoria: Government Printers.

Republic of South Africa. (2000). Municipal Systems Act. Pretoria: Government Printers.

Republic of South Africa. (2003). Municipal Financial Management Act. Pretoria: Government Printers.

Republic of South Africa. (2004). Municipal Property Rates Act. Pretoria: Government Printers.

Republic of South Africa. (2005). National Credit Act (34 of 2005). Pretoria: Government Printers.

Republic of South Africa. (2007). Municipal Fiscal Powers and Functions Act (12 of 2007). Pretoria: Government Printers.

Republic of South Africa. (2011). Ekurhuleni Metropolitan Municipality Councillors Handbook. Pretoria: Government Printer.

Republic of South Africa. (2018). The National Treasury Budget Review. Pretoria: Government Printer.

Republic of South Africa. (2020). National Treasury. 2010. Budget Review. Pretoria: National Treasury. 
Segal, L., \& Lehrer, M. (2012). The institutionalisation of stewardship: theory, propositions, and insights from change in the Edmonton Public Schools. Organization Studies, 33(2), 169-201. https://doi.org/10.1177/0170840611433994

Sikhakane, B. H., \& Reddy, P. S. (2011). Public accountability at the local government sphere in South Africa. African Journal of Public Affairs, 4(1), 85-102.

Stanleigh, J. (2016). Enterprise risk management: from incentives to controls (2nd ed.). London: Amazon

Thornhill, C. \& Cloete, J.J.N. (2014). South African Municipal Government and Administration. Pretoria: Van Schaik Publishers.

\section{Copyrights}

Copyright for this article is retained by the author(s), with first publication rights granted to the journal.

This is an open-access article distributed under the terms and conditions of the Creative Commons Attribution license (http://creativecommons.org/licenses/by/4.0/). 